\title{
TOURISM FOCUSED ANALYSIS OF NARROW-GAUGE RAILWAYS IN HUNGARY
}

\section{Tibor PRINCZ-JAKOVICS ${ }^{a}$, Gergely VASVÁRI ${ }^{b}$}

\author{
a BME Dept. of Environmental Economics, Address: H-1117 Magyar tudósok körútja 2., e-mail: \\ tprincz@eik.bme.hu \\ b BME Dept. of Highway and Railway Engineering, Address: H-1111 Mügyetem rakpart 3., e-mail: \\ vasvari.gergely@epito.bme.hu
}

Cite this article: Princz-Jakovics, T., Vasvári, G. (2019). Tourism focused analysis of narrow-gauge railways in Hungary. Deturope. 11(3), 80-92.

\begin{abstract}
Narrow-gauge railways showed rising significance as tourist attractions over the past few years in Hungary. This fact underlines the importance of complex evaluation regarding social, economic and environmental impact of development. This paper focuses on touristic and regional idiosyncrasies.

One of the purposes of this article is to provide a review of the national or regional policy documents affecting the development of narrow-gauge railways. The National Narrow-gauge Railway Development Concept (Országos Kisvasúti Koncepció; Transinvest Ltd, 2015) contains status overview, lists special targets and development alternatives both for infrastructure and for rolling stock. National Strategy for Tourism Development until 2030 (Nemzeti Turizmusfejlesztési Stratégia 2030; Hungarian Tourism Agency, 2017) also contains some relevant aspects; however goals for integrating narrow gauge railway services into main touristic attractions are not specific enough.

For economic and financial viability analysis of narrow-gauge railway operation and maintenance, existing railway lines were categorized by tourist and mixed passenger traffic during assessment. Based on these quantities traffic categories were formulated. In touristic passenger demand expected change implicated by development was linked to main indicators of national economy by regression analysis to support demand forecast.

For tourism-driven development of narrow-gauge railways identification of the attractive elements' touristic values has major importance. To support development plans of Hungarian narrow-gauge railways touristic potential matrices were devised, describing both current state and future estimates. The matrix of anticipated potentials may be used as directives for local touristic developments. Furthermore, several best-practice advices were also conceived to improve the effect of touristic utilization (e.g. use of hybrid timetables, capitalize on ecotourism, rebranding, etc). Two case studies (Narrow-gauge railways of Kecskemét and Balatonfenyves) are presented in the paper demonstrating the success of the advised methodology and for better identification of possible development options affected by the tourism potential. Best-practices show how the narrow-gauge rail services can help regional and local developments.
\end{abstract}

Keywords: narrow-gauge railways, policy documents, demand forecast, touristic potential, best-practice advices

\section{INTRODUCTION}

Narrow-gauge railways (Fig. 1) showed rising significance as tourist attractions over the past few years in Hungary. This fact underlines the importance of complex evaluation regarding social, economic and environmental impact of rail developments. Relevance of the topic is also indicated by the recent rehabilitation works and further developments started or announced by 
the government. This paper focuses on touristic and regional idiosyncrasies of narrow-gauge railways in Hungary.

Development possibilities and operation of individual railway lines are influenced by the ownership and legal status of the operator. This review deals with 29 forestry, company, museum and MÁV owned railways (excluding mining and other industrial railways). Narrowgauge railways are owned by MÁV Zrt., state forest companies, local governments or private organizations. The total length of track is $510 \mathrm{~km}$, of which $224 \mathrm{~km}$ is currently under operation: (gauges are almost exclusively $760 \mathrm{~mm}$ ). Rolling stock consists of 122 locomotives, 239 passenger cars and 329 freight cars. Further technical data on infrastructure and rolling stock of narrow-gauge railways is contained in the F\&B Consulting - Xellum 2008 study; Köller, 2016 series of articles and the Csiba J. et al, 2007 vehicle album.

Figure 1 Narrow-gauge railways of Hungary

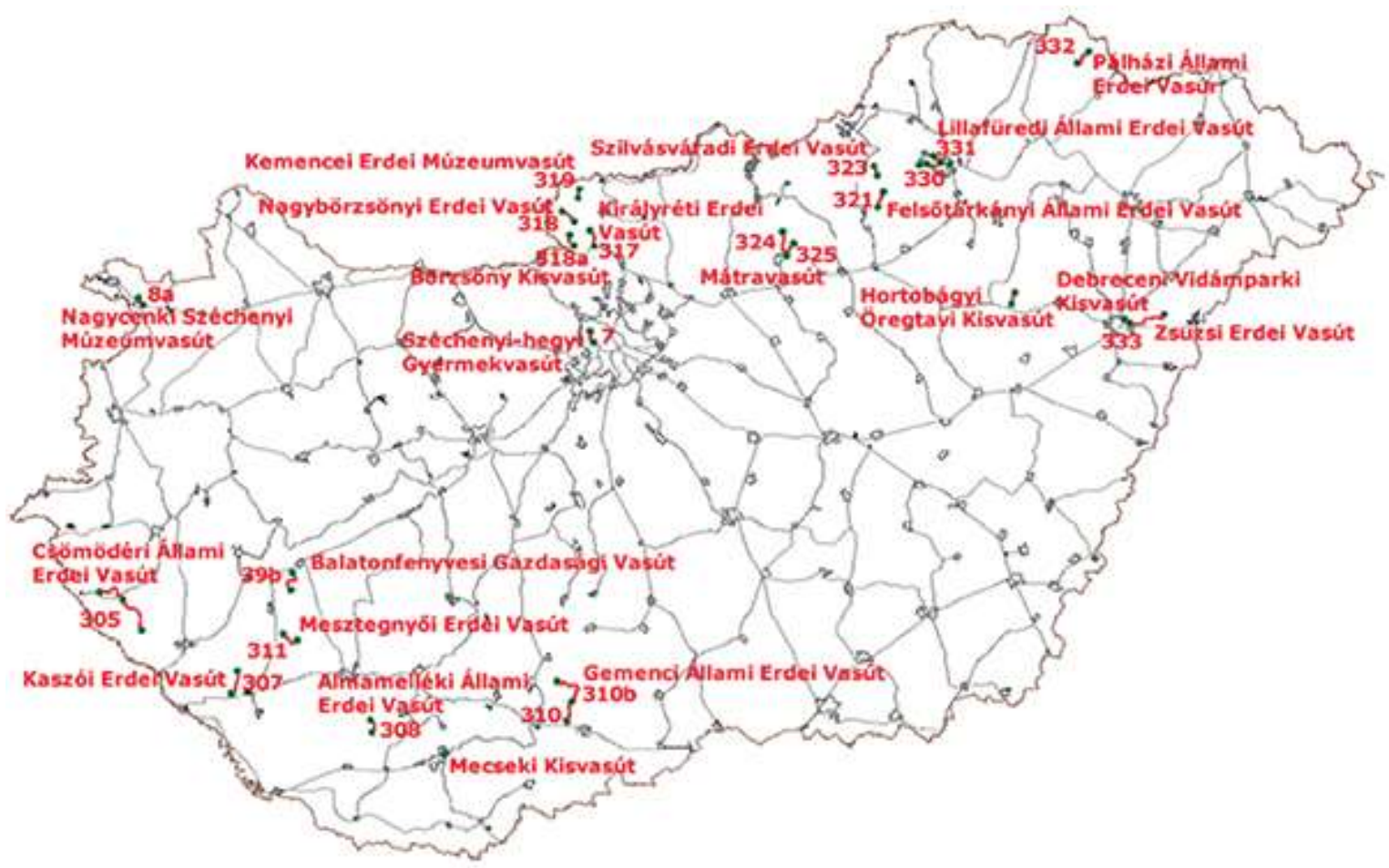

Source: Köller, 2016

Based on the above-mentioned ownership arrangements, the development of narrow-gauge passenger railways is also diverse. In most cases, these lines have been created by extending or modifying the freight tracks of mining or forest railways. Nowadays they serve mainly touristic purposes because of their location, but in many cases the public transport function also appears. That is why it is worthwhile to deal with touristic features in more detail. 
The analytical method starts with the exploration of relevant policies. Then demand forecast is done by categorizing characteristic traffic values of the lines. We analyzed passenger traffic tendencies indicated by national economy indicators and we estimated future traffic demand. In the second part of our article, we present methodological considerations that can be used to carry out more detailed analysis by definition of touristic potential matrices and lessons learnt by two relevant case studies.

\section{METHODOLOGICAL BACKGROUND}

Policy background

One of the purposes of this article is the review of national and regional policy documents affecting the development of narrow-gauge railways. The National Infrastructure Development Strategy /NKS/ (Strategy Consortium (2013)) and the National Railway Development Concept do not include narrow-gauge railways, although different types of infrastructure development should be harmonized. The strategy is in line with National Development and Regional Development Concept and its objective system presents 3 planning periods: very long term until 2041 (4 EU financial/supporting periods), long term: 2027 (2 EU financial/supporting periods) and medium term until 2020 (1 EU financial/supporting period). It is also mentioned in the document that a key issue of the Hungarian transport system is sustainable financing and that the required rehabilitation rate of the railway network is around $200 \mathrm{~km} /$ year compared to the recent $20 \mathrm{~km} /$ year.

As an independent policy document, at the end of 2015 the National Narrow-gauge Railway Development Concept (OKK, Országos Kisvasúti Koncepció; Transinvest Ltd, 2015a) was completed to provide an overview of such a special field of infrastructure. The OKK describes and analyses current conditions and future development possibilities of narrowgauge railways. It is a niche document, because it contains status overview, lists special targets and development alternatives both for infrastructures and rolling stocks of the narrow-gauge railway lines.

National Strategy for Tourism Development until 2030 (Nemzeti Turizmusfejlesztési Stratégia 2030; Hungarian Tourism Agency, 2017) also contains some relevant aspects: „A new method of attraction development and basic infrastructure development is to supplement a 
destination-based approach, that shall guarantee economic, social and ecological sustainability of the developed attractions, and ensure that visitors can enjoy high-quality experience".

Rail infrastructure is mentioned as one of the tourism-serving or supporting resources, and the supporting pillars identified within the Tourism Strategy include two relevant goals:

"H2. Family-friendly tourism: The essence of this principle is to establish tourist attractions which provide shared experiences for multiple generations, and the development of family friendly accommodation services and transport infrastructure."

"H3. Accessible tourism: The goal is to achieve physical and informational/communication accessibility as well as improve the direct physical accessibility of the attractions."

However it can be stated that the targets for the integration of narrow gauge railway services into main touristic attractions are not specific enough.

On local level special planning documents can be relevant. Sustainable Energy Action and Climate Plans (SECAPs) combine energy and climate issues, including interventions and development ideas for transport at the municipal level. The SECAPs quantify the most important indicators and identify interventions and development modes that help to achieve the objectives. Sustainable Urban Mobility Plans (SUMPs) contain long-term visions and clear implementation plans using participatory approach for a balanced and integrated development of all transport modes.

\section{Demand forecast}

For economic and financial viability analysis of narrow-gauge railway operation and maintenance, existing railway lines were categorized by tourist and mixed passenger traffic during assessment. Based on these quantities traffic categories were formulated. In touristic passenger demand expected change implicated by development was linked to main indicators of national economy by regression analysis to support demand forecast.

Considering the separated, linear nature of the narrow-gauge railway lines, expected passenger traffic performances (volume of traffic demand, choice of modes) were described with a corridor model. With this model, only travel patterns and expected traffic trends of the given line serve as a basis, without considering larger network components (urban, regional, etc.). Therefore, forecasted numbers of passengers are based on targeted surveys, or careful estimates should be made. The role of transport in the economy is determined by characteristics 
of traffic performance and the passenger transport market (Jászberényi- Pálfalvi, 2006; Jászberényi (Ed). 2018), so demand side analysis is necessary for assessment of the present situation and exploration of the tourism potential.

For touristic purposes elements affecting mode choice of passenger transport (Fig.2) are characterized by service level. A tourist's decisions are comfort-oriented, typically related to the level of enjoyment. Utility is important for efficiency-based decisions made by public transport users traveling to work (e.g. suburban transport). Both characteristics are important in mode choice of passenger transport (De Dios Ortúzar - Willumsen, 2011).

Figure 2 Components of passenger traffic for touristic purposes, mode choice

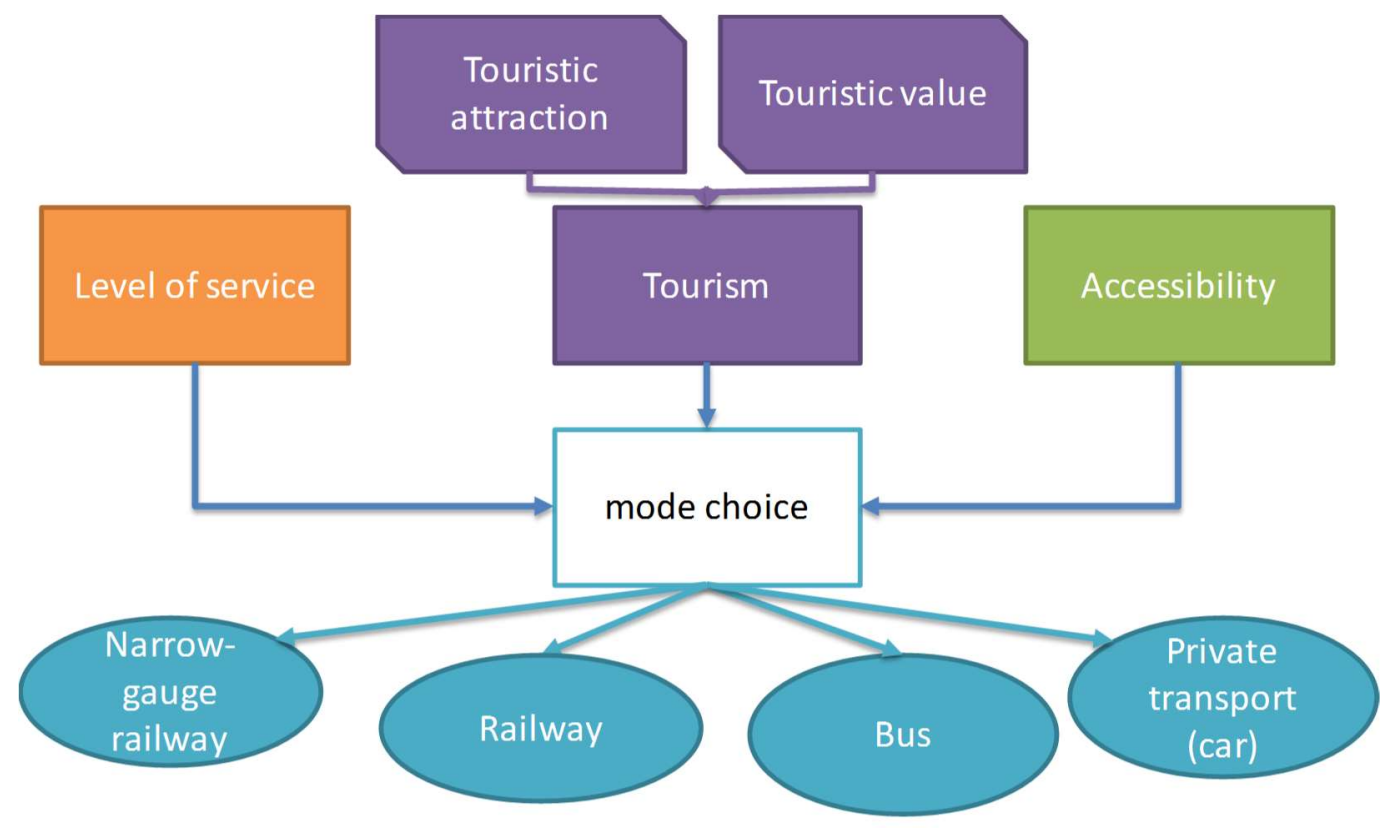

Source: Own work

Due to the wide range of touristic and mixed passenger traffic of different railway lines, creating traffic groups is necessary:

- low demand: 1,000-10,000 passengers / year (Ágmelléki ÁEV, Hortobágyi ÁEV, Nagycenki Széchenyi MV)

- medium demand: 10,000-100,000 passengers / year (Balatonfenyvesi GV, Zsuzsi Debreceni EV, FEVS, ÁEV Gemenc, Kemence EMV, Pálházi ÁEV)

- high demand: 100,000 -1,000,000 passengers / year (Széchenyi-hegyi GYV, Lillafüredi ÁEV, Mátravasút, Szilvásváradi ÁEV, Nyírvidéki KV, Kecskeméti KV) 
For future forecast correlation between touristic demand and national economic indicators should be analyzed. Fig. 3 shows how passenger traffic data - provided by railway operators - can be related to key indicators of national economy. Looking at changes in passenger traffic over time, it can be concluded that in most cases the economic crisis of 2008 led to a drastic decline later in 2010 , which was followed by a second and smaller decline in 2013. Examining dependence of change in the number of passengers related to national economy shows a clear positive trend.

Figure 3 Time trends of tourism-related passenger traffic compared to national economic indicators

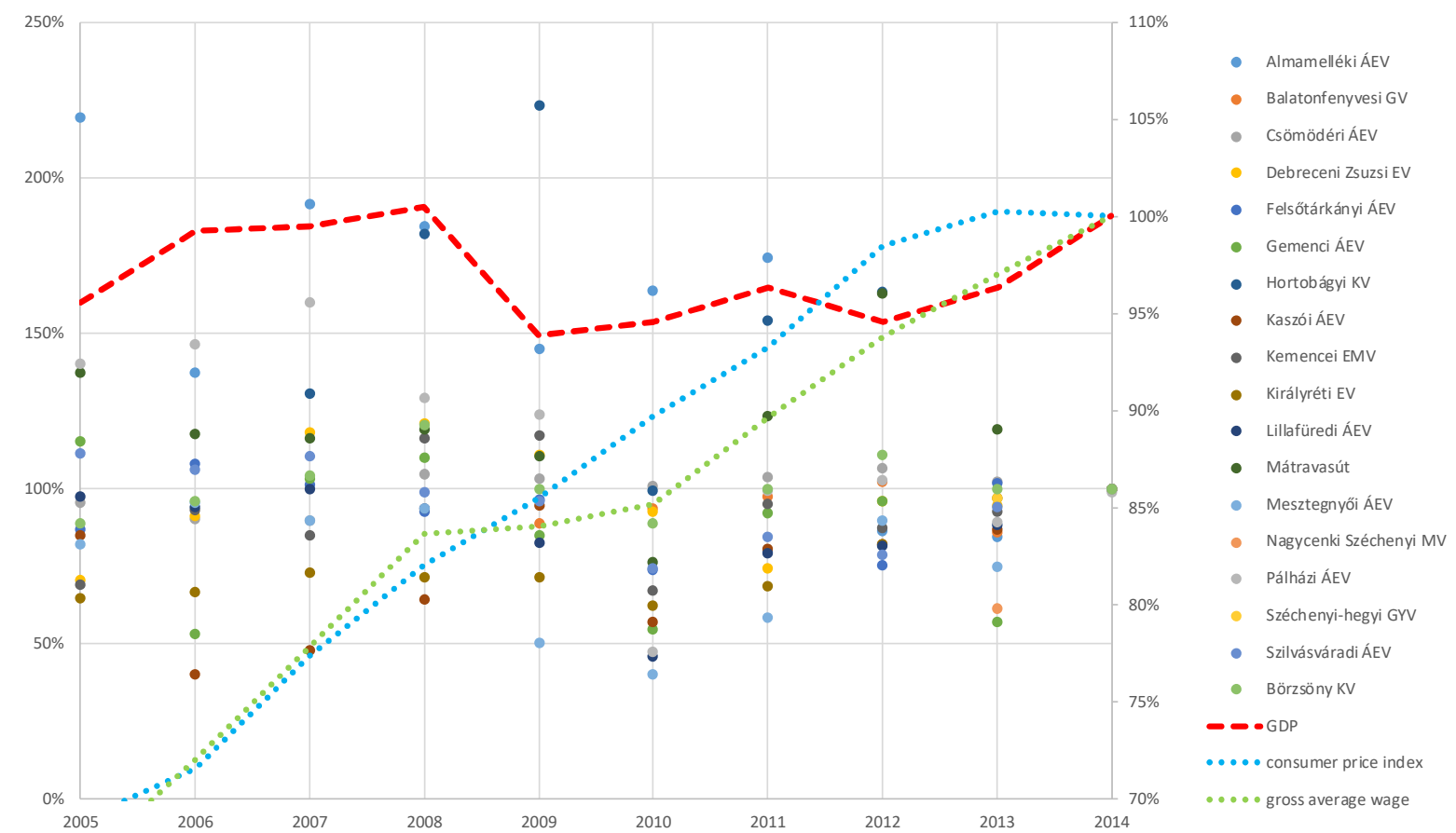

Left axis: passenger volume, $2014=100 \%$, right-hand axis: economic indicators, $2014=100 \%$. Source: Own edition based on the data of the Central Statistical Office and the survey of passenger traffic

For estimation of future passenger traffic in the short term, a slight upward trend can be forecasted based on observed tendencies of previous years. Cluster analysis of applied traffic categories (from small to high traffic volumes) can provide reliable data about expected dynamic increase in passenger numbers. Although cluster analysis was done for a small sample of railways, such evaluation of the traffic characteristics can efficiently help the planning and preparation processes of narrow-gauge railway developments. 


\section{ANALYSIS OF TOURISTIC POTENTIAL}

For tourism-driven development of narrow-gauge railways identification of touristic values of attractive elements has major importance. As touristic attractiveness of individual railway lines depends heavily on nearby attractions and program opportunities, the touristic potential effects of each line are described by a matrix. To support the development plans of narrow-gauge railways touristic potential matrices were devised, describing both the current state and future estimates. Fig. 4 shows relations of the matrices.

Figure 4 Touristic potential matrices

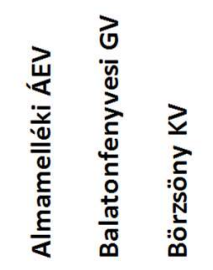

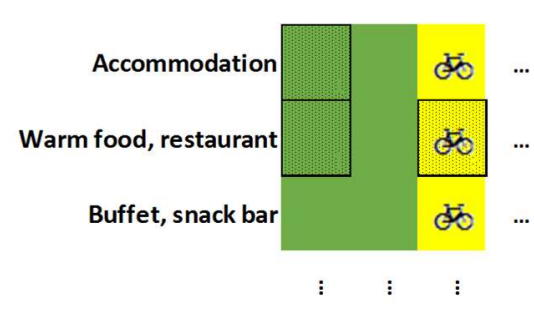

present state

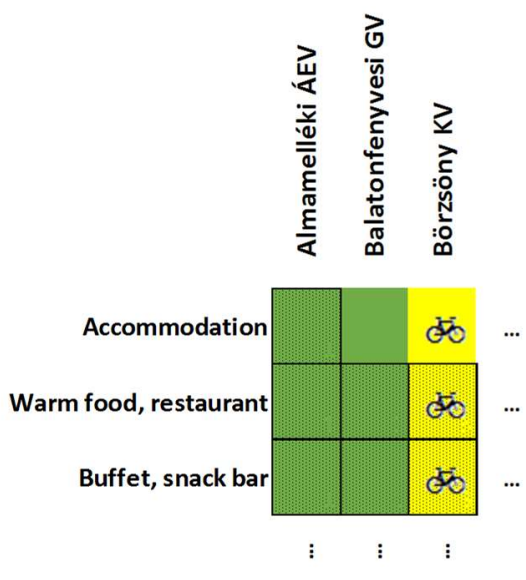

post-development

Source: Own work

Based on questionnaire interviews with railway operators the tourist destinations that were present nearby the lines were collected. For estimation of the full potential, touristic values of these attractive elements can be weighted and summarized. It will indicate the impact of facility attractiveness on the number of tourists appearing and volume of future passenger demand. New rail developments can be planned considering the impact of touristic potential. Fig. 5 shows existing tourist facilities in the vicinity of narrow-gauge railways. 
Figure 5 Tourist facilities in the vicinity of narrow-gauge railways, current state

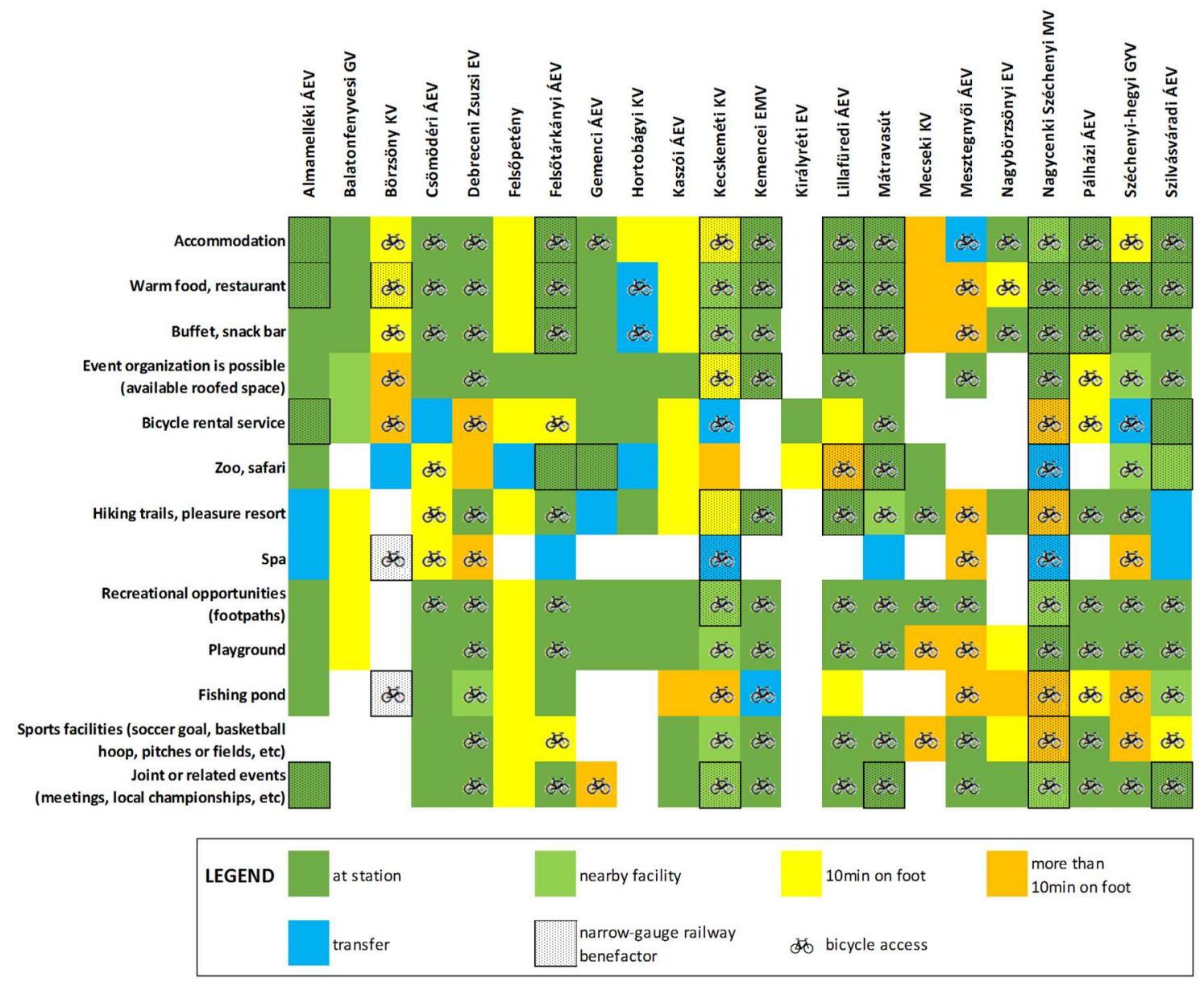

Source: Own work

"Narrow-gauge railway benefactor" marks that different discounts can be applied by presenting the travel certificate (train ticket).

The present state matrix of anticipated potentials may be used as a directive for local touristic developments. General best-practice advices are conceived to improve the effect of touristic utilization.

With the exception of a few lines, access to attractions, programs, and services offered by the railway are given, almost all of them are located at the stops or in their close area. Most of the tourist destinations are accessible by bicycle.

Eco-tourism can be part of the offered services at the lakeside or the extension of services related to national parks taking into account international examples (Lundberg - Fredman, 2012; EUROPARC Federation, 2010). Further support can be provided to evaluate achieved results and to use sustainability and performance indicators (Pomucz - Csete, 2015; Castellini - Sala, 2010). As a result of a relevant study (Vujko et al, 2018) it is also obvious that development of eco-tourism would raise the awareness of local residents about the importance of preserving protected areas. 
On a horizontal level, there are different facilities: easy-to-install items including bike rental options, or more difficult-to-install elements like zoo, spa and fishing ponds. However, in most cases, playgrounds, sports and recreational facilities are easily and quickly accessible, providing a good basis for improving eco-tourism. Since dining options are generally easy to access, long or full-day programs are also encouraged and help to create thematic routes.

Tourist destinations are in synergy with railways in almost half of cases. These are high level correlations, when railway management would have taken the necessary steps for better cooperation. Communication about touristic attractiveness - in a framework of destination management - usually focuses on brands (Bódis, 2017) and could strengthen the well-known characteristics of narrow-gauge railways.

\section{CASE STUDIES}

Two case studies (Narrow-gauge railways of Kecskemét and Balatonfenyves) are presented here demonstrating the success of advised methodology. Both lines belong to MÁV Hungarian State Railways.

Narrow-gauge railways of Kecskemét

The railway line was established in 1917 to transport timber and other products. Later the role in commuter traffic has also become significant. Line operation was cancelled in 2009 that lead to deterioration of tracks and buildings. Several re-opening initiatives have failed until now. A major obstacle is that the touristic characteristics of Kecskemét area have changed, and foreign visitors are less likely to seek out the sights associated with the wilderness. Location of the narrow-gauge railway line and its connection with city transport is also not favorable. Further problem is the accessibility of stations and stops (Transinvest Ltd, 2015c).

Touristic potential elements of Kecskemét narrow-gauge railways are:

- Natural attraction, Kiskunság National Park (sand forests and sandbanks, swamps, marshes, and salted swamps alternate).

- Shepherd museum, horse show at Bugac: Bugac is one of the most well-known Hungarian wildernesses and is still one of the central areas of indigenous Hungarian pet farming, part of the Kiskunság National Park.

- This railway has a lot of potential as passengers may find many attractive facilities along the line. Although access is limited in some cases (e.g. spa and bicycle rental could be reached only by transferring to other public transport services) it also can be perceived as balanced. 
- Important facilities with short dwelling time are close-by (catering, playground, sports facilities).

- Places for more time-consuming activities are also in the range of 10 minutes' walk time (event spaces, pleasure resort and accommodation).

- Larger facilities could also be reached by foot (zoo, fishing pond).

- Almost every one of these places is accessible by bicycle as well and has discounts or other solutions favoring passengers of the railway.

Reasonable development option is renovation of the railway line between Kecskemét and Bugac $(27.8 \mathrm{~km})$ reconnecting to many existing touristic attractions without the cost of complete line rehabilitation. Extension of the railway line to 'Kecskemét alsó' station is also possible (intermodal connection and parking facilities).

A mix of commuter and tourist functions can increase the number of potential users for a narrow-gauge railway therefore it is more sustainable. Railways that are suitable for commuter traffic due to their geographical location are also suitable for tourist purposes. Serving two different needs can be managed by setting up a hybrid schedule (which should also be considered in the case of exclusive tourist traffic). This schedule may include fast and slow trains on the line. Fast trains with low passenger capacity (e.g. a motor car) would transfer passengers at higher speeds, possibly for only a few stops' distance. Slow trains with higher capacity (two to three motor cars) would carry passengers at speeds that could favor local attractions. This kind of mixed schedule would not only make it possible to co-ordinate mixed (commuter and tourist) demand, but could also benefit tourists, who are curious about the sights, but only once. They could travel in one direction and spend time at the destination (e.g. in nature) rather than taking the return journey.

Schedule should also be flexible, adjusting to events taking place along the line.

Attractivity of discounts and other joint services should also be emphasized by offering program packages by the national park for train + walking tour or train + cycling trip (combined pricing as well). Other packages may offer program packages for train + horse show + regional cuisine, etc.

While most facilities by the railway may be accessed by bicycle, rental options are thin. Providing opportunities for bicycle rental, along with possibilities of transportation and storage would promote this environmentally friendly transportation mode.

Infrastructure development cost is around 14 million EUR (2015 prices). 
Narrow-gauge railways of Balatonfenyves

The first section of this railway line was put into operation in 1950. Initially, agricultural crops, peat and lime sludge were transported from the surrounding provinces to Balatonfenyves. Later commuting function became dominant, complemented by visitors of Csisztafürdő Spa. The narrow-gauge railway is still a popular tourist attraction in the Balaton region, bringing passengers between Lake Balaton and Somogyszentpál (5-7 pairs of train per day), however operation of the Csisztafürdő line section was cancelled in 2009 (Transinvest Ltd, 2015b).

After a 10-year long break, with the support of 2 million EUR, the railway will be partly developed: lines will operate till Csisztafürdő station again. Regional settlements submitted applications in 2016 under the leadership of Balatonfenyves with the goal to reopen the line to the thermal spa of Csisztapuszta, which is only 5-6 kilometers away from Lake Balaton. The works will include renovation of the terminal station's catering unit in Balatonfenyves. The range of tourist attractions directly linked to the narrow-gauge railway is poor.

Elements of the touristic potential of Balatonfenyves narrow-gauge railways to be developed are:

- There are opportunities for longer recreational activities nearby but there is no facilities close by for shorter recreation.

- Larger - more expensive - facilities are missing

- Bicycle access - along with rental options - is missing

- There are no beneficial offers from nearby facilities for tourist travelling with the narrow-gauge railway.

Developing a mixed and flexible schedule (commuter and touristic purpose) is also desirable (see details above). Adjusting this schedule to opening time of attractive places (bath) would also improve passenger comfort and attractiveness.

Installing soccer goals, or outdoor exercise machines at one or more stations would complement the already existing recreational attractiveness. It would be unreasonable to invest in larger facilities (i.e. zoo) but a dedicated pitch or field would further improve the sports facilities.

Providing opportunities for bicycle rental, transportation and storage makes existing facilities more accessible - as many of them are 10 minutes' walk away.

Thematic program proposals support ecotourism. A thematic route consists of several elements or sections that can be visited or spectated by stopping at route stations. All this can be created by additional stops, displaying attraction and activity advisory boards at stops; 
assigning pedestrian or cycling paths, photo paths or photo points between stops - allowing people this way to gain and accumulate experience and to increase the stay.

An additional possibility is to generate a circle route: pedestrian and cycling circuit can be assigned along shorter lines, giving visitors the opportunity to freely combine individual sections and walk around the area. For this reason, it is necessary to make wagons suitable for bicycle transportation, or to provide a range of bicycle rental services. Example for circle route is the Gemenc railway, after riding across the Gemenc Forest, reaching River Danube one can change to a cruise boat and return to the starting point on water. The Lillafüred ÁVV's Santa Train is a good example of combining attractiveness and transport function by introducing thematic days in partnership with local national park management. Topics come quite often from the cycle of seasons, from the periodic change of the natural environment (e.g. snowdrop search, deer rutting, crane migration).

\section{CONCLUSION}

In this paper we presented the diversity of narrow-gauge railways focusing on tourism-driven functions. We explored the policy background with analysis of relevant strategies and concepts to set goals for possible infrastructure developments. We categorized 29 railway lines by passenger traffic volumes and prepared a corridor-model for demand analysis, considering the high degree of independence of the narrow-gauge railways from the surrounding transportation network.

For better understanding of possible development options mapping of tourism potential characteristics is necessary on the basis of traffic and infrastructure, accounting for the uniqueness of narrow-gauge railways. Higher level rail services can help regional and local developments; that is the reason why regional development funds - as major financial sourcesare available for narrow-gauge railway owners.

We have also provided best practices and identified possible touristic project elements for two selected railway lines. The main conclusion concerning case studies is that innovative use of hybrid timetables and upgrading of ecotourism can improve the effect of touristic use of narrow-gauge railways.

\section{Acknowledgement}

The research reported in this paper was supported by the FIKP grant of EMMI in the frame of BMEBiotechnology (BME FIKP-BIO). 


\section{REFERENCES}

Bódis, G. (2017). A turizmus láthatatlanságának paradoxona: kommunikációs kihívások Turizmus Bulletin. [Paradox of the invisibility of tourism: communication challenges] 34. /XVII. 33-45

Castellini, V., \& Sala, S. (2010). Sustainable performance index for tourism policy development. Tourism Management. 31 (6). pp. 871-880.

Csiba, J., Malatinszky, S., Murárik, L., Németh, A., Tárczy, T., Vozáry, G., \& Zákonyi, G. (2007). Magyar Államvasutak Zrt. jármüalbum [Vehicle album of the Hungarian State Railways]. Budapest: MÁV Zrt. Kommunikációs Igazgatóság

De Dios Ortúzar, J.- Willumsen, L. G. (2011). Modeling Transport

Europarc Federation (2010). European charter for sustainable tourism in protected areas, Retrieved from https://www.europarc.org/library/europarc-events-andprogrammes/european-charter-for-sustainable-tourism/

F\&B Consulting - Kft-Xellum KF (2008). Magyarországon müködö kisvasutak helyzetének elemzése, fejlesztésük lehetöségei, fenntartható müködésük (készült az Önkormányzati és Területfejlesztési Minisztérium megbízásából) [Analysis of the state of narrow gauge railways operating in Hungary, possibilities for their development, sustainable operation (prepared on behalf of the Ministry of Local Government and Regional Development)], Budapest, 2008

Hungarian Tourism Agency (2017). Nemzeti Turizmusfejlesztési Stratégia 2030 [National Strategy for Tourism Development until 203]

Jászberényi, M., \& Pálfalvi, J. (2006). Közlekedés a gazdaságban. [Transport in economy]. Budapest: Aula Press

Jászberényi, M. (Ed.) (2018). Közlekedés, mobilitás, turizmus. [Transport, mobility and tourism]. Budapest: Budapesti Corvinus Egyetem

Köller L. (2016): Magyarországi kisvasutak- Országos Kisvasúti Koncepció [Hungarian Railways - The National Narrow-gauge Railway Development Concept], Sínek Világa ,2016/1., 15-21

Lundberg, C., \& Fredman, P. (2012). Success factors and constraints among nature-based tourism entrepreneurs. Current Issues in Tourism. 15 (7), 649-671

Pomucz A. B., \& Csete M. (2015): Sustainability Assessment of Hungarian Lakeside Tourism Development. Periodica Polytechnica-Social and Management Sciences 23:(2), 121-132

Stratégia Konzorcium (2013). Nemzeti Közlekedési Stratégia - Országos Vasútfejlesztési Koncepció. Készült a Közlekedésfejlesztési Koordinációs Központ megbízásából. [National Infrastructure Development Strategy- National Railway Development Concept. Prepared on behalf of the Transport Development Coordination Center]. Retrieved from http://www.kormany.hu/download/b/84/10000/Nemzeti\%2520K\%25C3\%25B6zleked\% 25C3\%25A9si\%2520Infrastrukt $\% 25 \mathrm{C} 3 \% 25 \mathrm{BAra}-$ fejleszt $\% 25 \mathrm{C} 3 \% 25 \mathrm{~A} 9 \mathrm{si} \% 2520$ Strat $\% 25 \mathrm{C} 3 \% 25 \mathrm{~A} 9$ gia.pdf

Transinvest Ltd (2015a). Országos Kisvasúti Koncepció (OKK) [The National Narrow-gauge Railway Development Concept (OKK)]. Budapest

Transinvest Ltd (2015b). Balatonfenyvesi kisvasút fejlesztési lehetöségeinek elömegvalósithatósági tanulmánya [Pre-feasibility study about the development options of Balatonfenyves narrow-gauge railway]. Budapest

Transinvest Ltd (2015c). Kecskeméti kisvasút fejlesztési lehetőségeinek elö-megvalósithatósági tanulmánya [Pre-feasibility study about the development options of Kecskemét narrowgauge railway]. Budapest

Vujko, A., Petrović, M.D., Gostović, D., Radovanović, M., \& Vuković, D. (2018). The Role of Natural Resources in the Ecotourism Development - Residents' Perceptions in Subotica (Northern Serbia). Deturope, 10(2), 112-123. 